\title{
MEASURING THE IMPACT OF AN INTERNATIONAL SERVICE-LEARNING PROJECT THROUGH COMMUNITY ASSESSMENT IN RWANDA
}

\author{
Anne Spear and Natasha Chapman
}

\section{Abstract}

In 2015, a university from Hong Kong led an international service-learning course to Kigali, Rwanda. The focus of the course was to install solar panels in individual bouseholds in a community, on the outskirts of Kigali, without access to electricity. The following year, the Hong Kong university partnered with a university in the United States and returned to Rwanda to expand the solar panel project in the same community. The central question of the qualitative impact assessment was, How, if at all, has the installation of solar panels impacted individual households and the community as a whole in the past year?

Data methods included semi-structured interviews and observations during visits to the 16 households who had received solar panels in previous iterations of the service-learning project. Findings demonstrating five reoccurring themes emerged: project implementation, economic savings, improvement of study environment for childhood, women's empowerment, and improved quality of life. A strategic government development plan, a sustained relationship between a university and a local organization, and the type of service project are highlighted as important factors. The importance of local participation in the design and implementation of the solar home systems (SHS) project is emphasized, and an unexpected impact on gender dynamics related to project design is explored.

Worldwide, universities are applying service-learning pedagogy across disciplines to enhance cognitive development, problem-solving skills, learning transfer, and global immersion experiences (Anitsal, Anitsal, Barger, \& Fidan, 2014; McKee, 2016; Ngai, Chan, Kwan, 2018). Service-learning is "a form of experiential education in which students engage in activities that address human and community needs together with structured opportunities intentionally designed to promote student learning and development” (Jacoby, 2015, p. 1). Research (Chan, 2012; Duffy, 2008; Oakes et al., 2002) has demonstrated the effective nature of experiential learning that 
allows students to apply theory and concepts learned in the classroom in a hands-on environment in order to develop a deeper understanding of intended outcomes.

There is rich literature on service-learning's impact on student learning; however, there is a gap in research regarding the impact on communities. Holland (2001) argues that service-learning must go beyond student outcomes, placing faculty responsible for measuring the impact on the community and community partners in order to improve and maintain the experience and the relationships. With an emphasis on the reciprocal nature of service-learning, it is surprising that there is a lack of attention given to the impact of the service-learning project on communities (Chisholm, 2003; Jacoby, 1996). According to Cruz and Giles (2000), from 1993 to 1999 , only eight articles examined service-learning impact on communities. The additional application of research methodology, time, and access needed to conduct such assessments explains some of the lack of research in the area (Cruz \& Giles, 2000).

Limited research examining the utility of service-learning projects in communities has emerged since 2000. For example, Harrington (2014) conducted a qualitative study to examine the opinions of community members on the benefits of international service-learning (ISL) projects in a Costa Rican community. Findings revealed that the community recognized intercultural exchange, economic advantages, transfer of knowledge, and productivity as benefits of the project and issues of community division and the creation of more work for community members as negative aspects of the service-learning projects. Wood, Banks, Galiardi, Koehn, \& Schroeder et al. (2011) contribute to the literature by examining how faculty and participants of an ISL trip perceived their impact on their host community. While this approach is unique, the limitation to such an approach is that it lacks community voice. Galiardi and Koehn (2011) picks up Holland's (2001) call by discussing how programs can be intentionally structured to include host community considerations through the inclusion of local partners and a meaningful commitment to local communities among student participants. Grain et al. (2019) conducted a photovoice study on an ISL project that included some of the structures that Galiardi and Koehn (2011) advocate for, such as a firm commitment to the local community. Using a social justice framework, the study found that relationships were central to community impact. A photo analysis revealed that the community valued the friendship, the learning that resulted from the exchange, and the facilitation of social change, which was a decrease in stigma around deafness.

This qualitative study contributes to the literature by examining the impact of an ISL project implemented by faculty and students from a Hong Kong university ( $U$ of HK) in a community in Kigali, Rwanda. The servicelearning project, conducted in 2014, included the installation of solar home systems (SHS) in 16 households. The following summer (2015), students and faculty from U of HK and from a university in the United States (U of US) traveled to Rwanda to conduct a qualitative impact assessment evaluating the impact of the SHS on the households and the community. The central question of this assessment was, How, if at all, has the installation of solar panels impacted individual households and the community in the past year? 


\section{Context}

The government of Rwanda is highly structured and regulates all development work done in the country. To work in Rwanda, an outside organization or institution must work with local associations and only on issues that are promoted by the government and that fit with development policies, such as Rwanda's 20/20 Vision (personal communication, May 2016; interview, Global Communities, October 19, 2016). Local associations are guided by the government regarding projects to conduct and where they are implemented. Each community is organized as a "cell" with a meeting place similar to a community hall. All households within a cell are within walking distance of the cell center. It was within this highly regulated and organized system that $\mathrm{U}$ of $\mathrm{HK}$ began to work with a local nonprofit organization (Rwanda NGO) to install solar panels in individual households.

An important element of service-learning is to identify projects that benefit partnering communities and that build on community's assets and existing resources. U of HK and Rwanda NGO decided to install SHS in individual households in a rural community located on the outskirts of the city of Kigali in order to address rural energy needs that align with the government's development goals. As far back as the 1970s, the international community has extended support for rural access to energy sources. More recently, international donors, including the World Bank, promote solar energy as an energy source that protects the environment as well as helps to alleviate poverty (Jacobson, 2007). The lack of accessible and appropriate technology in the local community coupled with the professional expertise of $\mathrm{U}$ of HK faculty resulted in a feasible SHS project for students in a technology-based service-learning course.

Research (Nieuwenhout et al., 2001; Pode, 2010; Wong, 2012) acknowledges that along with the diverse methods of implementing solar energy, there is a myriad of obstacles to operating and sustaining a successful system. In Wong's (2012) work with World Bank project designs, three barriers to effective rural energy projects were identified: finances, governance, and local participation. U of HK and Rwanda NGO's intentional consideration of these barriers throughout the development and implementation of their service-learning project enhanced the potential for a positive community impact from the SHS.

SHS are associated with high initial cost due to expensive equipment, such as batteries, light bulbs, and the solar panels themselves-particularly for poor households. With larger solar energy systems, households and businesses are required to absorb these costs, which create a financial burden on poorer families (Nieuwenhout et al., 2001). As part of their ISL project, the $\mathrm{U}$ of $\mathrm{HK}$ team provided the equipment and installation free of charge to the household recipients, thus mitigating any financial obligations from the community. With a yearly commitment to the community, the $\mathrm{U}$ of HK group continues to work with the trained community volunteers to maintain the SHS, supplement necessary inventory, and update equipment.

Governance is required to maintain and manage solar energy projects (Wong, 2012). U of HK's project is a relatively small-scale energy project. Despite this, Rwanda NGO took responsibility for regulating the installation while $\mathrm{U}$ of $\mathrm{HK}$ trained community trainers and monitored SHS equipment throughout the year. In addition, instructors from $\mathrm{U}$ of $\mathrm{HK}$ returned six months after the project to conduct a quantitative post-test assessment and evaluate the status of the SHS. 
A significant barrier to a successful solar energy system is local participation. Some studies suggest that users are less responsive and neglect maintenance repairs, due to lack of ownership, when the SHS is given to them without their involvement (Nieuwenhout et al., 2001). In addition, local communities must navigate the challenges of technical repairs and equipment failure (Pode, 2010; Wong 2012). In an effort to elicit local participation, Rwanda NGO organized the implementation of the solar panels in a systematic way. Rwanda NGO selected recipients of the 16 SHS based on economic need and the female head of household's involvement in what were called women's self-help groups_organizations centered on a culture of entrepreneurship, women empowerment, the sharing of resources, and community decision-making. Additionally, U of HK and Rwanda NGO staff trained existing community leaders to mount and make minor repairs to the SHS as well as to contact Rwanda NGO to report damaged equipment. At every household, Rwanda NGO staff and community members were involved in the installation of SHS alongside U of HK students.

\section{Methodology}

The service-learning experience required that students from the U of US participate in a spring semester course prior to engaging in a three-week ISL project in early summer. The ISL project involved an impact assessment of the SHS installed in households the previous year. During the spring course, students learned about the Rwanda context, intercultural communication and global competencies, the utility of impact assessments, and basic research design and implementation. The students were involved in constructing research questions, choosing data collection methods (interviews and observations), and developing interview questions. The students participated in human subject research training and were listed as co-investigators on the institutional review board proposal for the project. Of note, the primary purpose of including students in the research was for them to develop insight into the impact of ISL on the host community rather than to become proficient as qualitative researchers. This was not a research methods class, and the students, as undergraduates, had limited prior exposure to training in field work. However, engaging in research, guided by instructors, allows students to gain knowledge of the population and community in a unique way (Covan, 2001). By performing an impact assessment, instructors hoped that students would be able to make deeper connections with the community members and develop further insight into their potential footprints and the complex nature of service-learning relationships. In preparing students for the impact assessment, discussions were held about community partnerships, roles and responsibilities, power dynamics, and project limitations as well as the contextual understanding of community and household needs.

During the two weeks in Rwanda, students and faculty conducted field observations, house visits, and interviews with community members and key informants as the primary data collection methods. Students were divided into groups of three, with one faculty and a Rwandan translator assigned to each group. Face-toface interviews were conducted with members of the 16 households that received solar panels. Additionally, faculty involved in the May 2015 installation projects were interviewed, along with the Rwanda NGO staff 
who worked directly with the community to organize and manage development projects such as the solar panel installation.

In the second week of the service-learning project, faculty conducted an initial data analysis session with students as an active learning opportunity. Students learned how to code and created themes based on the recorded data. This activity was an initial analysis process as there were limitations for completing analysis in the field. The student's lack of experience coupled with the limited amount of time and regular access to technology prevented them from completing the analysis during the service-learning experience.

Returning from the field, U of US instructors applied Creswell's (2009) approach to qualitative analysis to transcribe and finish coding the interviews. A cross-platform application was used in order to further develop themes that described the impact of the solar panel installations on families and their community.

\section{Results}

In this section, results from the community assessment will be presented. The focus of this research was the impact of the SHS project on the community rather than an assessment of community attitudes and acceptance toward university faculty and students in their community.

From the community assessment, five recurring themes appeared: project implementation, economic savings, improvement of study environment for schoolchildren, women's empowerment, and improved quality of life. Project implementation emerged from SHS recipients' understanding of the solar technology, panel repair, and problem-solving around technology issues. A second major theme was economic savings. Households were able to save money by reducing the purchase of cost-inducing energy sources. Additionally, some families were able to earn money by asking neighbors to pay a small sum of money to charge their mobile phones. A third theme of improvement of study environment for schoolchildren was addressed during every interview. Based on anecdotal evidence, households reported that their children received better grades in school due to the ability to study at night after dark. The theme of women's empowerment also implicitly emerged throughout the community assessment. Last, solar panel recipients identified several subthemes under the larger theme of improved quality of life, which reflected positive impacts at both the individual and community level.

\section{Project Implementation}

The assessment demonstrated that the project implementation was carried out in a manner that allowed for community participation and project sustainability. As discussed by Nieuwenhout et al. (2001) and others, individual ownership and participation in the maintenance of the SHS is important in obtaining the most impact from the resource. In order to understand this success, this study examined the structure of the design, implementation, and follow-up. Rwanda NGO selected recipient households categorized by the Rwandan government as the poorest, most vulnerable families. Rwanda NGO has worked in partnership with the community 
for a number of years. One of Rwanda NGO's activities has been to assist women in organizing self-help groups. Thus, for the solar panel project, Rwanda NGO selected poor households of the women involved in the self-help groups. Rwanda NGO led trainings with the women about the purpose and potential benefits of solar energy via SHS, such as the use of lighting for the purpose of studying or working later in the evening.

Another success factor was the use of community technicians. Rwanda NGO identified local leaders to train as SHS technicians. Each household was assigned to a technician that recipients could call upon when a technical issue arose with the SHS. The impact assessment found that all but one household knew whom to call when there was a problem with the SHS. Although several households reported having technical problems with the solar panels at some point in the year, all of the SHS were functioning at the time of the assessment. Five of the women interviewed stated that they called the community technician to fix their SHS. Community technicians were able to fix the majority of the issues, but one of the local technicians reported that there were two cases in which they called Rwanda NGO to respond to and replace damaged equipment. U of HK staff reported that a SHS recipient, who moved homes after receiving the SHS, was able to disassemble and reassemble the SHS in the new house because of her training (field notes, May 2016).

These important factors demonstrate several points. First, the design of the implementation of the SHS was crucial for long-term sustainability success of the ISL project. As previous research (Nieuwenhout et al., 2001; Wong, 2012) found, flawed project designs contribute to failed energy projects. Furthermore, Rwanda NGO created a multi-layered participatory model. The trainings for recipients and community technicians, the bilateral communication, and the financial and technical support from Rwanda NGO and U of HK facilitated an environment that allowed community members to demonstrate agency by using the SHS in a manner that most benefited them.

\section{Economic Savings}

Another major theme that emerged from the data was economic savings. This study found that households' production and income did not significantly increase as a result of the SHS. However, households were able to save money due to reducing the purchase of cost-inducing energy sources. A household recipient reported, "Before, we were spending on lighting in the house. Buying kerosene and paying money for charging [our phones]. So, the money that we were spending for that, we are now saving." A Rwanda NGO staff emphasized that this savings should not be understated due to the potential uses and impact of the extra money. The women of the households that received a SHS reported that they use the extra money to support their children. One woman from a particularly poor family (made evident by the lack of animals and concrete floors) said, "We now can buy soap and books for our children.”

Additionally, four families stated they were able to earn money by asking neighbors to pay a small sum of money to charge their mobile phones. This varied by family. One family estimated that they made about 200 Rwandan franc (RWF) a day charging neighbors' phones, whereas another told us, "Sometimes our friends can charge [their phones] for free, but others pay 50 RWF." An elderly widow did not charge her neighbors to power 
their phones, and still another woman said that she tried to make some money requesting a fee for charging electronics, but neighbors stopped bringing their phones to her. Regardless of any income gained from charging neighbors' electronics in the past year, it is unlikely that this will be a reliable, sustained form of income for even the most successful family. The summer of the assessment, a community center was built that includes a free charging center.

Aside from money earned from charging cell phones, few households reported earning additional income or using the energy generated by the panels for income-producing activities despite this being a goal of Rwanda NGO and the SHS project. The SHS recipients were women who received training on how to develop small businesses through self-help groups, so it is surprising to find a lack of additional production or income-generating activities. One woman did report that she could work later in the evening, using the lighting to create products, such as paper bags, to sell. Several others suggested that they could consider new business ventures because of the energy source but had not yet implemented such a venture. There was a correlation between a woman's educational level and using the SHS for economic opportunities. Women who reported higher attainment in school were more likely to also report using the SHS for income-generating activities. These findings align with previous research (Jacobson, 2007; Mondal \& Klein, 2011) that, despite the intention for higher production and income through energy access, households do not often experience a rise in income as a result of gaining use of an energy source.

\section{Improvement of Study Environment for Schoolchildren}

A third theme of improvement of study environment for schoolchildren was addressed during every interview. All of the households that were interviewed stated the importance of their children's formal education and that the lighting produced from the SHS allowed their children to do homework and study with other children during the evening hours.

Based on anecdotal evidence, households reported that their children received better grades in school due to the ability to study after dark. One woman said, "Before they [the children] could not read or study at night because they did not have any lights. The student's grades have improved from 56 to 68 [points].” Other women emphasized the benefit of having a group of neighborhood children study together at homes with the SHS. They believed this peer interaction had benefits to their own child's learning. A woman, in the company of her husband, reported, "He [the son] gains knowledge by sharing knowledge with classmates. ... His marks have gone up.”

Although the women believed that the SHS had benefited their children's academic achievement, this assessment did not attempt to confirm their reports. However, during one interview, a mother showed the research team her son's progress report after describing that his improved marks were a result of studying at night using the light. The progress report actually showed that the child's grades had declined the second half of the school year, after the SHS was installed. Although it was true that this student was earning higher grades for the current year, six months after the installation of the SHS, he was also repeating the same grade. This demonstrates two 
important points: one, that there is a perception by participants that SHS is directly beneficial to children's educational improvement and two, that there is no documented evidence to confirm this perception.

\section{Women's Empowerment}

Women's empowerment was an implicit theme throughout the community assessment. With all household interviews, a woman of the household, who was a member of a saving groups and thus the reason her household was a recipient of the SHS, talked directly with the researchers. It was evident that these women had ownership over the SHS and the project. As one woman stated, "It helps the children read at night and it is easier for me to cook." Other women report the same activities when asked about how the SHS was used by the family. Only one family, a larger family with several of their older children present at the interview, reported that the light at night helps the husband with his work around the house. They understood the system and provided much of the maintenance, which included setting out the panels each day. All the women interviewed stated that even if they did not make income off the SHS, they were able to save money normally spent on gas lights and batteries for flashlights. The women reported that financial savings from the SHS were contributed to their self-help group or used toward family expenses such as soap or their children's education. At each interview, if the man of the house was present, he silently attended the interview, as if to supervise it.

This finding warrant attention. There is literature (Alston, 2014; Arora-Jonsson, 2011; Kronsell, 2013; Munien, 2014; Wong, 2009) addressing the connection between gender equality, energy technology, and access to energy resources. This assessment finds an illuminating gender dynamic contrary to the Rwandan context. Traditionally, women do not have ownership or accesses to resources, however, Rwanda NGO's implementation of this project permitted women to have control over the SHS and its benefits. Rwanda has made successful attempts at increasing women's representation at all levels, so it is not surprising that women were primary stakeholders in this project. However, there lacks evidence of any power shifts in gender relations due to an increase in representation, so the fact that women's voices were the only ones heard during interviews, as well as their ability to control the money saved and/or earned due to the SHS, is significant.

\section{Improved Quality of Life}

Solar panel recipients identified several subthemes under the larger theme of improved quality of life, which reflected positive impacts on both the individual and community level. Households said they were able to enjoy more entertainment and an increase in social activities at night. Families are able to listen to the radio, play games such as cards, and socialize at night.

Households said that security was better, and the community was safer due to the lights. One community leader said, "It is very important for there to be light so they [guards] can see and keep control. ... There is a decrease in stealing and grabbing in the night." Individual households also said that they felt safer because of having access to lighting at night. This benefit of the SHS was highlighted more often and more strongly by older, 
Table 1

Themes of Solar Panel Community Assessment

Project implementation

- Rwanda NGO's commitment to the community and strategic selection of recipient households

- Local leaders trained as SHS technicians

- All but one family could identify a designated technician

- Women of recipient households were open and willing to learn how to resolve technology issues

Economic davings

- Saved money on lighting material such as torches, gas/kerosene, batteries

- Families earned money on cell phone charging fees

- The higher the education of the women, the more likely they were able to take advantage of the economic opportunity

Improvement of study environment for schoolchildren

- Neighborhood children studied at houses with solar panels

- Students studied and read at night

- Households suggested that formal education was valuable, that the lighting allowed children to study, and that children were getting better marks

Women empowerment

- Women hoped for better business ventures due to the solar panels

- Limited basic economic activity such as charging for phones

- Saving money benefits the self-help group as individual contributions increase

Improved quality of life

- Lighting extended time in the evening for leisure and social activities

- Increased safety and security

- Increased social status

single woman-led households. Furthermore, the women identified that the SHS minimized safety concerns caused by the kerosene lanterns they used in the past for lighting.

Another benefit the women reported was a rise in social status within the community. This is significant given that the recipient households were the more marginalized families in the community due to poverty, and for some, being older single women households. Thus, the SHS systems gave them a higher social standing among their neighbors. Further research can explore what impact this shift has on the household members as well as the community as a whole.

Table 1 provides a summary of the themes that emerged as impacts for the installation of a SHS. With a growing interest in solar energy in resource-poor communities, as well as the establishment of ISL courses in engineering and computer science departments worldwide, the findings in Table 1 provide evidence of positive social impacts that could be expanded with the re-creation of similar or new ISL courses that build on these themes.

These findings demonstrate that the SHS had a positive impact on the recipient households in the past year. These are promising findings, and implications will be further explored in the discussion section.

\section{Discussion}

This research provides a descriptive account of the impact the solar panels have had on individual households and the community within a year of the service project cycle. Three major contributions resulting from this 
assessment warrant further insight: the importance of project design, the impact on gender equality, and the role of local participation. However, this single case study cannot be generalized to other ISL projects.

\section{Project Design}

It is likely that the success of this project design hinged on the following unique factors: (a) the type of project (SHS), (b) U of HK's long-term commitment to the community, and (c) the government's development strategy. Research, cited in a previous section, established the potential useful impact of SHS. While it is not clear if $U$ of HK or Rwanda NGO were intentional about implementing a project that already had demonstrated positive impact, it is worth considering researching documented success of projects for future ISL courses.

One of the tenets for best practices of ISL is a long-term, reciprocal relationship between the foreign institution and the host community. The findings of this impact assessment align with Galiardi and Koehn (2011) and Holland (2001) assertations that the involvement of local partners and a long-term commitment is necessary for a positive impact of ISL projects within communities. It is evident that these two factors were instrumental in the SHS project. The involvement of Rwanda NGO allowed for the ISL project to be successfully built on the assets of the community by working within existing organizations, such as the women's self-help groups. With intimate knowledge of the community, Rwanda NGO was able to identify appropriate recipients and prepare them through SHS trainings.

One of the potential contributions toward the emerging positive impacts of this ISL project was the country context. The government of Rwanda's explicit and organized approach to foreign development projects (which an ISL project is categorized) is unique. As illustrated, these government requirements helped facilitate the nature of the partnership between $\mathrm{U}$ of HK and Rwanda NGO, the role of women as recipients, and the approval of the project itself. The $\mathrm{U}$ of $\mathrm{HK}$ does similar ISL courses in other countries, such as Cambodia, where there is less government oversight but a sustained local NGO partnership and local participation. A comparison study can provide more insight into the relationship between government involvement and ISL projects.

Another interesting observation around the ISL design is the effect of the theoretical framework. These findings, when compared to Grain et al.'s (2019) study in Uganda, highlights how the theoretical approach to the ISL program dictates the potential community impact. Grain et al. (2019) evaluated an ISL project that applied a social justice lens in creating an ISL course by considering historical and current inequalities. In contrast, the $U$ of HK approach focused on tasks and project outcomes without additional social and historical analysis. While both ISL projects had a multi-year commitment to the community, the theoretical and pedagogical lens in which the service-learning project was structured affected the communities' reporting of the impact. In Uganda, the increased attention of the rights and visibility of the deaf was most fully appreciated as well as the relationships developed between the students and community members. In Rwanda, the female recipients talked of furthering their financial empowerment but used language that highlighted the benefits of the SHS itself. There was no mention about any exchange with the students who installed the SHS.

The gender dynamic found in this assessment speaks to the project design but also brings out the potential for 
larger societal impact. Attention should be drawn to the opportunity to address gender inequality through an undergraduate service-learning project and in partnership with students, staff, community partners, and community members. The research was centered on the voices and experiences of women who were most impacted by the SHS project. Women, rather than their husbands, took the lead in speaking to the researchers. All women reported ownership of the SHS and its uses. Furthermore, the households reported that women control the money saved. Such degree of influence and agency emerged from the data, two concepts not commonly experienced by women in Rwanda. The NGO staff explained that the method in which the project was introduced to the households and the structure of connecting the SHS project with the women's self-help group helped facilitate the husbands' acceptance of allowing the women to control the money. Otherwise, the men would demand the money from their wives. There is reason to support further inquiry related to increased agency for women and changing household dynamics as a result of SHS projects.

\section{Role of Local Participation}

There were also multiple levels of local participation and ownership of the project: the women at the household level, the technicians at the community level, and Rwanda NGO at the national level. This multi-layered engagement is important to the sustainability of the SHS project as well as to the partnership between higher education institutions and national organizations. At the national level, the Rwanda NGO assisted U of HK in the overall organization of the project as well as implementing the structure. Rwanda NGO followed the government strategy by how they identified the community, chose recipient households, and organized the women. $\mathrm{U}$ of HK led training for both the Rwanda NGO in order to position them as the overseers of the success of the SHS but also with community technicians. This additional layer of participation proved useful when evaluating the maintenance and functioning of the SHS. Each woman reported calling on the technician during the year for technical assistance, although most women were proficient at the daily maintenance and minor troubleshooting of the equipment. As described earlier, one woman was able to independently uninstall and reinstall her SHS upon moving to a new location. While visiting her home, a $\mathrm{U}$ of $\mathrm{HK}$ faculty member pointed to how proficient and skilled her iteration of the implementation was compared to the first installation primarily completed with students.

\section{Conclusion}

This impact assessment provides student, faculty, community members, and the community partner a descriptive account of the impact the SHS has had on the households and rural Rwandan community. This research contributes to the service-learning conversations in various ways. It provides a model for ISL that emphasizes an asset-based approach, the role of qualitative research, and sustaining long-term, collaborative relationships with community partners and members. The central question of how the solar panels effected the households in and of itself certainly adds to the understanding and evaluation of a technology-focused service-learning project. 
A significant finding illuminated the gender dynamics that emerged after the implementation of solar panels on homes. Women controlled the use of the solar energy as well as the savings and income generated from the solar panels. This contribution begs attention to the impact of the service-learning project on gender or family dynamics. Although the SHS is perceived to be vital to the improvement of factors such as a quality of life, economics, and education, there are additional impacts on community relationships, gender, and family dynamics that go beyond the technology itself and elicit further exploration.

\section{Limitations}

It is heartening to find evidence that ISL has potential to positively impact community members as it does student learning and development. However, it is important to note that there are some limitations to this study. As a qualitative assessment of a single case, the results cannot be generalized. It would be beneficial to study the potential factors that appear to have contributed to the success of the ISL project, such as the governmental strategy and Rwanda NGO's involvement. A more in-depth examination would require a different study design. This study was not designed to capture the nuances of such contextual factors. Furthermore, the assessment was limited in nature and did not explore the presence of two foreign universities and the related dynamic. Neither did it investigate the relationship between Rwanda NGO and the local community nor the partnership between Rwanda NGO and U of HK. Thus, it is possible that there are harms or additional positive impacts that have not been revealed through this study. Further research is encouraged to explore these issues.

\section{References}

Alston, M. (2014). Gender mainstreaming and climate change. Women's Studies International Forum, 47, 287294.

Anitsal, M., Anitsal, I., Barger, B., \& Fidan, I. (2014). Service learning across disciplines and countries. Atlantic Marketing Journal, 3(2), 130-142.

Arora-Jonsson, S. (2011). Virtue and vulnerability: Discourses on women, gender and climate change. Global Environmental Change, 21(2), 744-751.

Chan, C. (2012). Exploring an experiential learning project through Kolb’s Learning Theory using a qualitative research method. European Journal of Engineering Education, 37(4), 405-415.

Chisholm, L. (2003). Partnerships for international service-learning. In B. Jacoby \& Associates (Eds.), Building partnerships for service-learning (pp. 259-288). San Francisco, CA: Jossey-Bass.

Covan, E. K. (2001). Employing Service-Learning to Teach Research. Educational Gerontology, 27, 623-627.

Creswell, J. W. (2009). Research design: Qualitative, quantitative, and mixed methods approaches (3rd ed.). Thousand Oaks, CA: Sage.

Cruz, N. I., \& Giles, D. E., Jr. (2000). Where’s the community in service-learning research? Michigan Journal of Community Service Learning, 28-34. 
Duffy, J. (2008). Village empowerment: Service-learning in continuity. International Journal for Service Learning in Engineering, 3(2), 1-17.

Galiardi, S., \& Koehn, J. (2011). Strategies to mitigate the negative and accentuate the positive impacts of international service-learning on host communities. Partnerships: A Journal of Service-Learning $\Xi^{\circ}$ Civic Engagement, 2(1), 1-12.

Grain, K., Katumba, T., Kirumira, D., Nakasiita, R., Nakayenga, S., Nankya, E., . . \& Ssegawa, M. (2019). Coconstructing knowledge in Uganda: Host community conceptions of relationships in international servicelearning. Journal of Experiential Education, 42(1), 22-36. doi:10.1177/1053825918820677

Harrington, K. L. (2014). The impacts of service-learning on communities: Perspectives from the people (Unpublished master's thesis). University of Georgia. Athens, GA. Retrieved from https://getd.libs.uga.edu/pdfs/ harrington_keneisha_1_201405_mal.pdf

Holland, B. A. (2001). A Comprehensive Model for Assessing Service-Learning and Community- University Partnerships. New Directions for Higher Education, (114).

Jacobson, A. (2007). Connective power: Solar electrification and social change in Kenya. World Development, $35(1), 144-162$.

Jacoby, B. (1996). Service-learning in today's higher education. In B. Jacoby \& Associates (Eds.), Service-learning in higher education (pp. 3-25). San Francisco, CA: Jossey-Bass.

Jacoby, B. (2015). Service-learning essentials: Questions, answers, and lessons learned. San Francisco, CA: JosseyBass.

Kronsell, A. (2013). Gender and transition in climate governance. Environmental Innovation and Societal Transitions, 7, 1-15.

McKee, R. (2016). International service-learning: Common goals and issues among programs across disciplines. Journal of Service-Learning in Higher Education, 5(1).

Mondal, A. H., \& Klein, D. (2011). Impacts of solar home systems on social development in rural Bangladesh. Energy for Sustainable Development, 15(1), 17-20.

Munien, S. (2014). Rural energy profiles and the role of solar energy in climate change mitigation-A gendered perspective. Agenda, 28(3), 115-126.

Ngai, G., Chan, S. C. F., \& Kwan, K.-P. (2018). Challenge, meaning, interest, and preparation: Critical success factors influencing student learning outcomes from service-learning. Journal of Higher Education Outreach and Engagement, 22(4), 55-80.

Nieuwenhout, F. D. J., van Dijk, A., Lasschuit, P. E., van Roekel, G., van Dijk, V. A. P., Hirsch, D., ... \& Wade, H. (2001). Experience with solar home systems in developing countries: A review. Progress in Photovoltaics: Research and Applications, 9(6), 455-474.

Oakes, W., Duffy, J., Jacobius, T., Linos, P., Lord, S. M., Schultz, W. W., \& Smith, A. (2002, February). Servicelearning in engineering. Paper presented at the Frontiers in Education Conference, Boston, MA.

Pode, R. (2010). Solution to enhance the acceptability of solar-powered LED lighting technology. Renewable and Sustainable Energy Reviews, 14(3), 1096-1103. 
Wong, S. (2009). Climate change and sustainable technology: Re-linking poverty, gender, and governance. Gender E̊ Development, $17(1), 95-108$.

Wong, S. (2012). Overcoming obstacles against effective solar lighting interventions in South Asia. Energy Policy, 40, 110-120.

Wood, C. A., Banks, S., Galiardi, S., Koehn, J., \& Schroeder, K. (2011). Community impacts of international service-learning and study abroad: An analysis of focus groups with program leaders. Partnerships: A Journal of Service-Learning and Civic Engagement, 2(1), 1-23.

\section{Authors}

DR. ANNE SPEAR (aspear@umd.edu) is an affiliate at the University of Maryland (UMD), College Park, where she earned a PhD in International Education Policy. She served as an instructor for the Leadership Studies Program at UMD. Dr. Spear's current work focuses on strengthening effectiveness and productivity among global and virtual teams.

NATASHA CHAPMAN, PHD (chapman3@umd.edu) is the lecturer and advisor for the Global Engineering Leadership Program at the University of Maryland (UMD), College Park, and also serves as an affiliate Assistant Professor with the Department of Counseling, Higher Education, and Special Education. Dr. Chapman has been a leadership educator for 15 years having also served as the coordinator for the Leadership Studies Program at UMD, a Professor for Leadership Studies at West Virginia University, and the Director of the Texas Christian University's Leadership Center. 